Int. J. Electrochem. Sci., 14 (2019) 2925 - 2932

International Journal of

ELECTROCHEMICAL

SCIENCE

WWW.electrochemsci.org

\title{
Electrochemical Characterization of poly(N-methylaniline) Films
}

\author{
Aziz Yăgan \\ Chemistry Education, Dicle University, 21280, Diyarbakır, Turkey \\ E-mail: yagan@dicle.edu.tr
}

doi: $10.20964 / 2019.03 .78$

Received: 25 October 2018 / Accepted: 22 December 2018 / Published: 7 February 2019

Poly( $N$-methylaniline) (PNMA) films were obtained by cyclic voltammetry on Pt electrode in $0.1 \mathrm{M}$ $N$-methylaniline dissolved in an electrolyte solution of $1.0 \mathrm{M} \mathrm{HBF}_{4}$. Electrochemical characterization of the polymer films was investigated using electrochemical techniques like cyclic voltammetry and electrochemical impedance spectroscopy (EIS) in $\mathrm{HBF}_{4}$ solutions. The influence of PNMA layer thickness and applied potential on impedance characteristics were also investigated. The results indicated that the electroactive behaviors of the films mainly depend on the polymer thickness and applied potentials.

Keywords: Poly(N-methylaniline); Electrochemical characterization; Impedance spectroscopy; Electrolyte effect

\section{$\underline{\text { FULL TEXT }}$}

(C) 2019 The Authors. Published by ESG (www.electrochemsci.org). This article is an open access article distributed under the terms and conditions of the Creative Commons Attribution license (http://creativecommons.org/licenses/by/4.0/). 